\title{
Use of $3 \times 2$ tables with an intention to diagnose approach to assess clinical performance of diagnostic tests: meta-analytical evaluation of coronary CT angiography studies
}

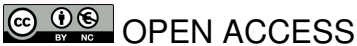

\author{
Georg M Schuetz research assistant ${ }^{1}$, Peter Schlattmann professor of medical statistics ${ }^{2}$, Marc \\ Dewey chief consultant ${ }^{1}$
}

${ }^{1}$ The Charité-Universitätsmedizin Berlin, Humboldt-Universität zu Berlin, Freie Universität Berlin, Department of Radiology, 10117 Berlin, Germany;
${ }^{2}$ The Department of Medical Statistics, Informatics and Documentation, University Hospital of Friedrich Schiller University Jena, Jena, Germany

\begin{abstract}
Objective To determine whether a $3 \times 2$ table, using an intention to diagnose approach, is better than the "classic" $2 \times 2$ table at handling transparent reporting and non-evaluable results, when assessing the accuracy of a diagnostic test.

Design Based on a systematic search for diagnostic accuracy studies of coronary computed tomography (CT) angiography, full texts of relevant studies were evaluated to determine whether they could calculate an alternative $3 \times 2$ table. To quantify an overall effect, we pooled diagnostic accuracy values according to a meta-analytical approach.
\end{abstract}

Data sources Medline (via PubMed), Embase (via Ovid), and ISI Web of Science electronic databases.

Eligibility criteria Prospective English or German language studies comparing coronary CT with conventional coronary angiography in all patients and providing sufficient data for a patient level analysis.

Results 120 studies (10 287 patients) were eligible. Studies varied greatly in their approaches to handling non-evaluable findings. We found 26 studies (including 2298 patients) that allowed us to calculate both $2 \times 2$ tables and $3 \times 2$ tables. Using a bivariate random effects model, we compared the $2 \times 2$ table with the $3 \times 2$ table, and found significant differences for pooled sensitivity ( 98.2 ( $95 \%$ confidence interval 96.7 to $99.1) v 92.7$ (88.5 to 95.3$)$ ), area under the curve $(0.99$ (0.98 to 1.00$) v$ 0.93 (0.91 to 0.95$)$ ), positive likelihood ratio (9.1 (6.2 to 13.3) $v 4.4$ (3.3 to 6.0$)$ ), and negative likelihood ratio $(0.02$ (0.01 to 0.04$) v 0.09$ (0.06 to 0.15); $(\mathrm{P}<0.05)$ ).

Conclusion Parameters for diagnostic performance significantly decrease if non-evaluable results are included by a $3 \times 2$ table for analysis (intention to diagnose approach). This approach provides a more realistic picture of the clinical potential of diagnostic tests.

\section{Introduction}

Clinical decisions in medicine are largely made on the basis of information gained from diagnostic testing. Against the background of more than 15 years of development and experience in evidence based medicine ${ }^{1}$ and in times of comparative effectiveness research, ${ }^{2}$ new diagnostic techniques have to be critically assessed and proven to be effective before they can be used on a wide scale. Diagnostic accuracy studies comparing an index test with a reference or gold standard and meta-analyses combining the results of many individual studies to explore a test's diagnostic potential are an important and basic step in the overall evaluation process of the validity of a new diagnostic test. ${ }^{3}$ However, previous studies have shown that methodological deficits could affect the estimated diagnostic accuracy of a test. ${ }^{5-7}$

In non-invasive coronary imaging, technical innovations such as dual source ${ }^{8}$ and 320 row computed tomography $(\mathrm{CT})^{9}$ have improved spatial and temporal resolution while reducing radiation. As a result of these developments, CT has evolved into the primary modality for non-invasively evaluating native coronary arteries over the past 10 years. ${ }^{10}{ }^{11}$ Cardiac CT examinations performed on newer generation scanners (with at least 64 rows) have the potential to reliably rule out substantial stenoses in patients with a low to intermediate pretest likelihood, and thus can spare them an invasive catheterisation. ${ }^{112}$ Nonetheless, when exploring studies from this highly topical field of diagnostic imaging, we are confronted with a fundamental deficiency-non-evaluable results from the index test that are classifiable as neither positive nor negative. This problem has not yet been resolved adequately, although it has the most direct influence on diagnostic accuracy results. Coronary CT angiography studies commonly deal with 
non-evaluable results of the index test in different ways, especially when transferring a segment based (or vessel based) to a patient based evaluation: non-evaluable segments are simply excluded, patients with non-evaluable segments are excluded, or patients with non-evaluable segments are generally considered either positive or negative. This exclusion leads to bias and overestimation of diagnostic accuracy at the study level, which is then introduced into meta-analyses pooling data from such studies.

In this article, therefore, we aimed to investigate how different approaches of dealing with non-evaluable results lead to variations in overall diagnostic accuracy values, using a systematically compiled pool of studies of non-invasive coronary CT angiography. We proposed an approach for the transparent reporting of such results - by applying a $3 \times 2$ table - to avoid biased overestimation of diagnostic accuracy.

\section{Methods}

We performed a systematic search for CT studies of coronary angiography on a patient level using recently reported methods. ${ }^{13}{ }^{14}$ Briefly, we searched Medline (via PubMed), Embase (via Ovid), and ISI Web of Science databases. The main inclusion criteria were prospective study design, conventional coronary angiography as the reference standard in evaluating native coronary arteries, both tests performed in all patients, and CT scanners with at least 12 detector rows. The studies also had to provide results allowing calculation of per patient $2 \times 2$ tables for obstructive coronary artery disease (defined as at least one coronary stenosis of at least $50 \%$ ) and had to be published in English or German. We excluded studies explicitly stated to be retrospective or if they potentially overlapped with other studies. The original meta-analysis has further methodological details. ${ }^{13}$ The update search was performed on 2 February 2011. We then checked the full texts of the pool of relevant studies for the possibility to calculate an alternative $3 \times 2$ table on the per patient level - that is, giving adequate background information on single patients with coronary CT images of non-evaluable quality and the patient's real health status defined by the invasive catheter examination (gold standard).

\section{Statistical analysis}

For the meta-analytical data evaluation, we used an exact binomial rendition ${ }^{15}$ of the bivariate, mixed effects regression model developed by van Houwelingen and colleagues ${ }^{16}$ and modified for synthesis of diagnostic test data. ${ }^{17}$ We calculated summary diagnostic performance values including $95 \%$ confidence intervals from standard data of a $2 \times 2$ table (after excluding non-evaluable results) or the $3 \times 2$ table, including non-evaluable results either in the "false negative" or the "false positive" cell of a $2 \times 2$ table (worst case scenario) according to the results of the reference standard (intention to diagnose principle). For visually illustrating and directly comparing these two approaches, we combined two summary receiver operating characteristics curves ${ }^{18}$ into one graph. We also evaluated two further common approaches, categorically declaring non-evaluable results as either positive ${ }^{19}$ or negative. ${ }^{20}$

Figures 1 to $3 \Downarrow \Downarrow \Downarrow$ summarise the different approaches and their influence on sensitivity and specificity. The "classic" $2 \times 2$ table (fig 1) does not take into account non-evaluable results. Figure 2 shows the effects of excluding non-evaluable results or declaring them as either positive or negative. Figure 3 presents the $3 \times 2$ table, suggested for transparent reporting and for avoiding overestimation of sensitivity and specificity (with an intention to diagnose approach). We used the MIDAS module $^{21}$ for Stata, version 11 (StataCorp), and Proc GLIMMIX in SAS, version 9.2 (SAS Institute), to perform the analysis.

\section{Results}

We found 120 eligible studies ${ }^{8} 192022-137$ of coronary CT angiography (including 10287 patients) that compared each patient's results with conventional coronary angiography. We checked their full texts for the possibility to calculate an alternative $3 \times 2$ table.

Eleven $(11 / 120=0.092=9 \%)$ studies did not have non-evaluable results. Twenty six (22\%) studies simply excluded non-evaluable segments, and 23 (19\%) excluded patients with non-evaluable segments from analysis. Twenty six (22\%) studies declared all patients with non-evaluable segments as positive, and seven $(6 \%)$ declared them as negative. Three (3\%) studies reported findings in a $3 \times 2$ table while retaining all non-evaluable results. For $24(20 \%)$ studies, it remained unclear how non-evaluable segments were transferred to the patient level.

For 26

studies $^{8} 9192022253235414548616272969799105111112115116121125126129$ (including 2298 patients), it was possible to calculate alternative $3 \times 2$ tables (table $1 \Downarrow$ ). Sensitivity, area under the curve, and positive and negative likelihood ratios indicated significantly decreased diagnostic performance $(\mathrm{P}<0.05)$, compared with the $2 \times 2$ table (table $2 \Downarrow$ ).

Other approaches, which are sometimes also referred to as "intention to diagnose" but only declare patients with non-evaluable segments as either positive or negative, overestimated either sensitivity or specificity (table 2). Figure $4 \Downarrow$ compares the findings for the $2 \times 2$ table and the $3 \times 2$ table calculations combining summary receiver operating characteristics curves in one graph.

\section{Discussion}

Our analysis indicated a lack of consensus on how studies of non-invasive CT coronary angiography handle non-evaluable outcomes, and our meta-analytical examination shows how different yet common strategies can distort diagnostic accuracy results. The "classic" $2 \times 2$ table (fig 1) does not hold enough information to show the true range of possible results, and forces investigators to use one of the approaches in figure 2: by simply excluding non-evaluable results, sensitivity and specificity are artificially increased; and by declaring non-evaluable results as either positive or negative, either sensitivity or specificity is overestimated, and the absolute numbers of non-evaluable results are not accessible.

From a clinical perspective, patients with non-evaluable results will have to be further evaluated to rule out or confirm significant disease. Therefore, classifying these patients as positive and taking into account that they will need further investigation seems to be clinically appropriate in several scenarios. However, in relation to the true diagnostic capabilities of the test itself, such an approach might be misleading.

Only by transforming the $2 \times 2$ table into a $3 \times 2$ table and reporting all results accordingly will researchers make study outcomes fully transparent. Furthermore, using an intention to diagnose principle (fig 3 ) for calculation ensures that both sensitivity and specificity are not overestimated. The range of possible outcomes for sensitivity and specificity between the two scenarios of declaring non-evaluable results as positive or negative represents the overall effect of non-evaluable results. But summarising these two scenarios with a conservative approach - that is, including non-evaluable results as false 
positives and false negatives - seems to summarise the true clinical potential of the diagnostic test most adequately.

Acknowledging the fact that the reference standard can also yield non-evaluable results, the $3 \times 2$ table could even be extended further to a $3 \times 3$ table, also transparently reporting these non-evaluable results of the reference standard. However, non-evaluable results of conventional coronary angiography were rare in our analysis $(0.1 \%)$.

As early as 1987 , Simel and colleagues ${ }^{138}$ proposed using the $3 \times 2$ table as the standard method for reporting absolute numbers of diagnostic test results. To our knowledge, they were the first to propose a solution to overcome the problem. To appraise diagnostic accuracy, they used new operational definitions of sensitivity and specificity, calculating them traditionally but including further test values (especially the overall test yield) necessary to account for non-evaluable results and to characterise the diagnostic test. Based on the $3 \times 2$ table, we systematically analysed different approaches of handling non-evaluable results on coronary CT angiography and found that this method significantly altered the results regarding diagnostic accuracy in a meta-analytical evaluation. By applying an intention to diagnose approach, we avoided the overestimation of sensitivity and specificity by including non-evaluable results in our calculation. We believe that this approach is most convenient, because the customary method of characterising diagnostic accuracy as a pair of sensitivity and specificity, without the need for further test yield values, is preserved.

In addition to the fact that there is no consensus on how to handle non-evaluable results, our full text evaluation showed a general lack of comprehensive reporting of results by coronary CT angiography studies. Thus, in $109(109 / 120=0.908=91 \%)$ studies, the authors encountered non-evaluable results on the segment or vessel level, but for $24(22 \%)$ of these studies, it remained unclear how, or if at all, the results were transferred to the patient level. Furthermore, only $26(26 / 85=0.306=31 \%)$ of the remaining 85 studies provided enough background information to enable us to calculate alternative $3 \times 2$ tables. Only three $(3 / 120=0.025=3 \%)$ studies from our pool originally reported non-evaluable results in a $3 \times 2$ table.

Our findings indicate a lack of awareness of these issues of poor reporting and inconsistent handling of non-evaluable results, which continues to persist; of the investigated 120 studies from the young field of non-invasive coronary CT angiography, 106 (88\%) were published after 2005 . This problem is probably not restricted to coronary CT angiography but could greatly affect diagnostic accuracy studies in general. Firstly, the methodological differences in handling non-evaluable results compromise the comparability of diagnostic accuracy data from different studies. Furthermore, the common approaches of handling non-evaluable results (fig 2) distort findings regarding diagnostic accuracy. This distortion affects not only sensitivity and specificity but also predictive values and likelihood ratios, which has important implications for clinical decision making.

If we assume that the pool of studies investigated here is representative of all studies available on the topic, the overall potential of coronary CT angiography as a test to rule out significant stenoses is weakened, because the confidence interval of the negative likelihood ratio exceeded the value of $0.1(0.09$ (0.06 to 0.15$).{ }^{139}$ Therefore, these biased results will probably also have an effect at higher levels of evidence, and will therefore affect the evaluation of new diagnostic technologies even more. This scenario could happen when such biased data are combined in systematic reviews and meta-analyses that constitute an important basis for health technology assessment reports, which influence decision and policy makers.

The STARD checklist (Standards for the Reporting of Diagnostic Accuracy Studies) ${ }^{140}$ and the QUADAS tool (Quality Assessment of Diagnostic Accuracy Studies Included in Systematic Reviews), ${ }^{141}$ the most common reporting guideline and assessment tool for diagnostic accuracy studies, do not pay enough attention to the problem of non-evaluable results. STARD item 19 postulates the reporting of results as "including indeterminate and missing" results, and STARD item 22 requests investigators to report on how these results were handled. Item 13 of the original QUADAS checklist asks "Were uninterpretable/intermediate results reported?"- despite recognising the topic, the question is restricted to the level of reporting. But the mere inclusion of "non-evaluable results as positives" does not necessarily mean that absolute numbers of non-evaluable results will be accessible to readers. In this regard, it is especially disappointing that QUADAS- $2,{ }^{142}$ the revised version of the original QUADAS tool, ${ }^{141}$ does not consider non-evaluable results explicitly. This situation underlines the need to find a consensus on how to report and integrate non-evaluable diagnostic test results in the future.

Although we believe that the issues discussed here are inherent to all diagnostic tests, our analysis is limited to a specific field of medical imaging. Therefore, the effect on diagnostic accuracy estimates in other medical fields should be evaluated in further research.

Responsible reporting is an essential component of research conduct. ${ }^{143}$ To improve the reliability and value of medical research by promoting transparent and accurate reporting, the EQUATOR (Enhancing the QUAlity and Transparency Of health Research) network has been established. ${ }^{144}$ This international initiative aims to bring together all stakeholders with an interest in the improvement of publications and medical research, including authors, journal editors, and peer reviewers. Among other things, the network's website (www.equatornetwork.org) offers a comprehensive online library with the available reporting guidelines.

\section{Conclusions}

For diagnostic accuracy studies in particular, complete reporting of all results on all levels (at the segment, vessel, and patient levels), if applicable, is the basis for fully characterising a test's diagnostic potential. As a minimum, authors of diagnostic accuracy studies should adopt the STARD checklist ${ }^{140}$ to meet general reporting standards, and medical journals should consistently encourage (or even demand) the use of this checklist for submitting manuscripts on studies of diagnostic accuracy. Beyond that, a standardised approach for authors of diagnostic accuracy studies on coronary CT angiography (and on any other topic) could be to report their findings in a $3 \times 2$ table. If this approach is performed following intention to diagnose principles, all results become transparent to readers, and authors will be more cautious in interpreting an overly optimistic presentation of diagnostic test accuracy.

Funding: This study was supported by a grant of the German Federal Ministry of Education and Research (Bundesministerium für Bildung und Forschung, BMBF; FKZ: 01KG1110) for meta-analyses as part of the joint programme "clinical trials" of the BMBF and the German Science Foundation (DFG). The supporting organisation had no involvement in the design, conduct, analysis, or manuscript preparation of this study. Competing interests: All authors have completed the Unified Competing Interest form at www.icmje.org/coi_disclosure.pdf (available on request 


\section{What is already known on this topic}

Diagnostic accuracy studies and meta-analyses of pooled results constitute an important step in the evaluation of diagnostic tests There is no consensus on how diagnostic accuracy studies should handle non-evaluable results, and common approaches to do so overestimate diagnostic accuracy

\section{What this study adds}

In a pool of studies of non-invasive coronary CT angiography, we saw no consensus on how to handle non-evaluable results Common approaches of dealing with non-evaluable results led to significant differences in overall diagnostic accuracy estimates Transparent reporting of findings in a $3 \times 2$ table including non-evaluable results and applying an intention to diagnose approach can provide a more realistic picture of the clinical potential of diagnostic tests

from the corresponding author) and declare: PS and MD are supported by a grant of the German Federal Ministry of Education and Research (BMBF) for meta-analyses as part of the joint programme "clinical trials" of the BMBF and the German Science Foundation (DFG); PS is also supported by another grant of the (DFG) (Schl 3-1) and has received lecture fees from Bayer-Schering; MD has received grant support from Heisenberg Program of the German Research Foundation (DFG) for a professorship (DE 1361/14-1), European Regional Development Fund (20072013 2/05, 20072013 2/48), German Heart Foundation/German Foundation of Heart Research ( $F / 23 / 08, F / 27 / 10$ ), a joint programme from the German Research Foundation (DFG) and the German Federal Ministry of Education and Research (BMBF) for meta-analyses (01KG1013, 01KG1110), GE Healthcare, Bracco, Guerbet, and Toshiba Medical Systems; MD has received lecture fees from Toshiba Medical Systems, Guerbet, Cardiac MR Academy Berlin, and Bayer

(Schering-Berlex); MD is a consultant to Guerbet and one of the principal investigators of multicentre studies (CORE-64 and 320) on coronary CT angiography sponsored by Toshiba Medical Systems; MD is the editor of Coronary CT Angiography and Cardiac CT, both published by Springer, and offers hands-on workshops on cardiovascular imaging; institutional master research agreements for MD exist with Siemens Medical Solutions, Philips Medical Systems, and Toshiba Medical Systems; GMS is a physician working as a research assistant in MD's working group, whose salary is financed by a BMBF grant for meta-analyses granted to MD; no other relationships or activities that could appear to have influenced the submitted work.

Ethics approval: Not required.

Contributors: MD had the initial idea for the manuscript; MD and GMS conceived and designed the study. MD, GMS, and PS were responsible for analysis and interpretation of data; GMS drafted and MD and PS critically revised the article for important intellectual content; All authors approved the final manuscript; MD is the guarantor. The article was initiated by the authors, who had full control of the data analysis and interpretation, and there was no industry sponsorship.

Data sharing: No additional data available.

Rosenberg W, Donald A. Evidence based medicine: an approach to clinica problem-solving. BMJ 1995;310:1122-6.

2 Sox $\mathrm{HC}$, Greenfield S. Comparative effectiveness research: a report from the Institute of Medicine. Ann Intern Med 2009;151:203-5.

3 Fryback DG, Thornbury JR. The efficacy of diagnostic imaging. Med Decis Making 1991;11:88-94.

4 Lijmer JG, Leeflang M, Bossuyt PM. Proposals for a phased evaluation of medical tests. Med Decis Making 2009;29:E13-21.

5 Lijmer JG, Mol BW, Heisterkamp S, Bonsel GJ, Prins MH, van der Meulen JH, et al. Empirical evidence of design-related bias in studies of diagnostic tests. JAMA 1999;282:1061-6.

6 Whiting P, Rutjes AW, Reitsma JB, Glas AS, Bossuyt PM, Kleijnen J. Sources of variation and bias in studies of diagnostic accuracy: a systematic review. Ann Intern Med 2004;140:189-202

7 Rutjes AW, Reitsma JB, Di Nisio M, Smidt N, van Rijn JC, Bossuyt PM. Evidence of bias and variation in diagnostic accuracy studies. CMAJ 2006;174:469-76.

8 Leschka S, Stolzmann P, Desbiolles L, Baumueller S, Goetti R, Schertler T, et al. Diagnostic accuracy of high-pitch dual-source $\mathrm{CT}$ for the assessment of coronary stenoses: first experience. Eur Radiol 2009;19:2896-903.

9 Dewey M, Zimmermann E, Deissenrieder F, Laule M, Dubel HP, Schlattmann P, et al. Noninvasive coronary angiography by 320-row computed tomography with lower radiation exposure and maintained diagnostic accuracy: comparison of results with cardiac catheterization in a head-to-head pilot investigation. Circulation 2009;120:867-75.
10 National Institute for Health and Clinical Excellence. DG3 Computed tomography (CT) scanners for cardiac imaging-Somatom Definition Flash, Aquilion One, Brilliance iCT and Discovery CT750: guidance. NICE, 2012.

11 Dewey M. Cardiac CT. Springer, 2011.

12 Schlattmann P, Schuetz GM, Dewey M. Influence of coronary artery disease prevalence on predictive values of coronary CT angiography: a meta-regression analysis. Eur Radiol 2011;21:1904-13.

13 Schuetz GM, Zacharopoulou NM, Schlattmann P, Dewey M. Meta-analysis: noninvasive coronary angiography using computed tomography versus magnetic resonance imaging. Ann Intern Med 2010;152:167-77.

14 All you need to read in the other general journals. BMJ 2010;340:c754

15 Chu H, Cole SR. Bivariate meta-analysis of sensitivity and specificity with sparse data: a generalized linear mixed model approach. J Clin Epidemiol 2006;59:1331-2; author reply 32-3.

16 Van Houwelingen $\mathrm{HC}$, Zwinderman $\mathrm{KH}$, Stijnen T. A bivariate approach to meta-analysis. Stat Med 1993;12:2273-84

17 Reitsma JB, Glas AS, Rutjes AW, Scholten RJ, Bossuyt PM, Zwinderman AH. Bivariate analysis of sensitivity and specificity produces informative summary measures in diagnostic reviews. J Clin Epidemiol 2005;58:982-90.

18 Arends LR, Hamza TH, van Houwelingen JC, Heijenbrok-Kal MH, Hunink MG, Stijnen T. Bivariate random effects meta-analysis of ROC curves. Med Decis Making 2008;28:621-38.

19 Garcia MJ, Lessick J, Hoffmann MH. Accuracy of 16-row multidetector computed tomography for the assessment of coronary artery stenosis. JAMA 2006;296:403-11.

20 Achenbach S, Ropers D, Pohle FK, Raaz D, von Erffa J, Yilmaz A, et al. Detection of coronary artery stenoses using multi-detector CT with $16 \times 0.75$ collimation and $375 \mathrm{~ms}$ rotation. Eur Heart J 2005:26:1978-86.

21 Dwamena BA. Midas: a program for meta-analytical integration of diagnostic accuracy studies in Stata. Division of Nuclear Medicine, Department of Radiology, University of Michigan Medical School, 2007.

22 Alkadhi H, Scheffel H, Desbiolles L, Gaemperli O, Stolzmann P, Plass A, et al. Dual-source computed tomography coronary angiography: Influence of obesity, calcium load, and heart rate on diagnostic accuracy. Eur Heart J 2008;29:766-76.

23 Andreini D, Pontone G, Pepi M, Ballerini G, Bartorelli AL, Magini A, et al. Diagnostic accuracy of multidetector computed tomography coronary angiography in patients with dilated cardiomyopathy. J Am Coll Cardiol 2007;49:2044-50.

24 Bayrak F, Guneysu T, Gemici G, Sevinc D, Mutlu B, Aytaclar S, et al. Diagnostic performance of 64 -slice computed tomography coronary angiography to detect significant coronary artery stenosis. Acta Cardiol 2008:63:11-7.

25 Bonmassari R, Muraglia S, Centonze M, Coser D, Stoppa G, Disertori M. Noninvasive detection of coronary artery stenosis with 16 -slice spiral computed tomography in a population at low to moderate risk for coronary artery disease. J Cardiovasc Med (Hagerstown) 2006;7:817-25.

26 Brodoefel H, Burgstahler C, Tsiflikas I, Reimann A, Schroeder S, Claussen CD, et al. Dual-source CT: effect of heart rate, heart rate variability, and calcification on image quality and diagnostic accuracy. Radiology 2008;247:346-55.

27 Budoff MJ, Dowe D, Jollis JG, Gitter M, Sutherland J, Halamert E, et al. Diagnostic performance of 64-multidetector row coronary computed tomographic angiography for evaluation of coronary artery stenosis in individuals without known coronary artery disease: results from the prospective multicenter ACCURACY (Assessment by Coronary Computed Tomographic Angiography of Individuals Undergoing Invasive Coronary Angiography) trial. J Am Coll Cardiol 2008:52:1724-32.

28 Cademartiri F, Maffei E, Palumbo A, Malago R, Alberghina F, Aldrovandi A, et al. Diagnostic accuracy of 64 -slice computed tomography coronary angiography in patients with low-to-intermediate risk. Radiol Med (Torino) 2007;112:969-81.

29 Carrascosa P, Capunay C, Bettinotti M, Goldsmit A, Deviggiano A, Carrascosa J, et al. Feasibility of gadolinium-diethylene triamine pentaacetic acid enhanced multidetector computed tomography for the evaluation of coronary artery disease. J Cardiovasc Comput Tomogr 2007; 1:86-94.

30 Chow BJ, Dennie C, Hoffmann U, So D, de Kemp RA, Ruddy TD, et al. Comparison of computed tomographic angiography versus rubidium-82 positron emission tomography for the detection of patients with anatomical coronary artery disease. Can J Cardiol 2007;23:801-7.

31 Coles DR, Wilde P, Oberhoff M, Rogers CA, Karsch KR, Baumbach A. Multislice computed tomography coronary angiography in patients admitted with a suspected acute coronary syndrome. Int $J$ Cardiovasc Imaging 2007;23:603-14.

32 Cornily JC, Gilard M, Le Gal G, Pennec PY, Vinsonneau U, Blanc JJ, et al. Accuracy of 16-detector Multislice Spiral Computed Tomography in the initial evaluation of dilated cardiomyopathy. Eur J Radiol 2007;61:84-90.

33 Davin L, Lancellotti P, Bruyere PJ, Gach O, Pierard L, Legrand V. Diagnostic accuracy of computed tomography coronary angiography in routine practice. Acta Cardiologica 2007;62:339-44

34 Deetjen AG, Conradi G, Mollmann S, Ekinci O, Weber M, Nef H, et al. Diagnostic value of the 16-detector row multislice spiral computed tomography for the detection of coronary artery stenosis in comparison to invasive coronary angiography. Clin Cardiol 2007;30:118-23. 
35 Dewey M, Teige F, Schnapauff D, Laule M, Borges AC, Wernecke KD, et al. Noninvasive detection of coronary artery stenoses with multislice computed tomography or magnetic resonance imaging. Ann Intern Med 2006;145:407-15.

36 Ehara M, Surmely JF, Kawai M, Katoh O, Matsubara T, Terashima M, et al. Diagnostic accuracy of 64-slice computed tomography for detecting angiographically significant coronary artery stenosis in an unselected consecutive patient population: comparison with conventional invasive angiography. Circ J 2006;70:564-71.

37 Erdogan N, Akar N, Vural M, Canbay A, Kayhan T, Sahin D, et al. Diagnostic value of 16-slice multidetector computed tomography in symptomatic patients with suspected significant obstructive coronary artery disease. Heart Vessels 2006;21:278-84.

38 Gaudio C, Mirabelli F, Pelliccia F, Francone M, Tanzilli G, Di Michele S, et al. Early detection of coronary artery disease by 64-slice multidetector computed tomography in asymptomatic hypertensive high-risk patients. Int J Cardiol 2009;135:280-6.

39 Ghersin E, Litmanovich D, Dragu R, Rispler S, Lessick J, Ofer A, et al. 16-MDCT coronary angiography versus invasive coronary angiography in acute chest pain syndrome: a blinded prospective study. AJR Am J Roentgenol 2006;186:177-84

40 Ghostine S, Caussin C, Daoud B, Habis M, Perrier E, Pesenti-Rossi D, et al. Non-invasive detection of coronary artery disease in patients with left bundle branch block using 64-slice computed tomography. J Am Coll Cardiol 2006;48:1929-34.

41 Gilard M, Cornily JC, Pennec PY, Joret C, Le Gal G, Mansourati J, et al. Accuracy of multislice computed tomography in the preoperative assessment of coronary disease in patients with aortic valve stenosis. J Am Coll Cardiol 2006;47:2020-24.

42 Grosse C, Globits S, Hergan K. Forty-slice spiral computed tomography of the coronary arteries: assessment of image quality and diagnostic accuracy in a non-selected patient population. Acta Radiol 2007;48:36-44.

43 Hacker M, Jakobs T, Hack N, Nikolaou K, Becker C, von Ziegler F, et al. Combined use of 64-slice computed tomography angiography and gated myocardial perfusion SPECT for the detection of functionally relevant coronary artery stenoses. First results in a clinical setting concerning patients with stable angina. Nuklearmedizin 2007;46:29-35.

44 Halon DA, Gaspar T, Adawi S, Rubinshtein R, Schliamser JE, Peled N, et al. Uses and limitations of 40 slice multi-detector row spiral computed tomography for diagnosing coronary lesions in unselected patients referred for routine invasive coronary angiography. Cardiology 2007;108:200-9.

45 Hausleiter J, Meyer T, Hadamitzky M, Zankl M, Gerein P, Dorrler K, et al. Non-invasive coronary computed tomographic angiography for patients with suspected coronary artery disease: The Coronary Angiography by Computed Tomography with the Use of a Submillimeter resolution (CACTUS) trial. Eur Heart J 2007;28:3034-41.

46 Henneman MM, Schuijf JD, Jukema JW, Lamb HJ, de Roos A, Dibbets P, et al. Comprehensive cardiac assessment with multislice computed tomography: evaluation of left ventricular function and perfusion in addition to coronary anatomy in patients with previous myocardial infarction. Heart 2006;92:1779-83.

47 Henneman MM, Schuijf JD, Pundziute G, van Werkhoven JM, van der Wall EE, Jukema $J W$, et al. Noninvasive evaluation with multislice computed tomography in suspected acute coronary syndrome: plaque morphology on multislice computed tomography versus coronary calcium score. J Am Coll Cardiol 2008;52:216-22.

48 Herzog BA, Husmann L, Burkhard N, Gaemperli O, Valenta I, Tatsugami F, et al. Accuracy of low-dose computed tomography coronary angiography using prospective electrocardiogram-triggering: First clinical experience. Eur Heart J 2008;29:3037-42.

49 Herzog C, Nguyen SA, Savino G, Zwerner PL, Doll J, Nielsen CD, et al. Does two-segment image reconstruction at 64-section CT coronary angiography improve image quality and diagnostic accuracy? Radiology 2007;244:121-9.

50 Herzog C, Zwerner PL, Doll JR, Nielsen CD, Nguyen SA, Savino G, et al. Significant coronary artery stenosis: comparison on per-patient and per-vessel or per-segment basis at 64-section CT angiography. Radiology 2007;244:112-20

51 Hoffmann MH, Shi H, Schmitz BL, Schmid FT, Lieberknecht M, Schulze R, et al. Noninvasive coronary angiography with multislice computed tomography. JAMA 2005:293:2471-8.

52 Hoffmann U, Moselewski F, Cury RC, Ferencik M, Jang IK, Diaz LJ, et al. Predictive value of 16 -slice multidetector spiral computed tomography to detect significant obstructive coronary artery disease in patients at high risk for coronary artery disease: patient-versus segment-based analysis. Circulation 2004;110:2638-43.

53 Johnson TR, Nikolaou K, Busch S, Leber AW, Becker A, Wintersperger BJ, et al. Diagnostic accuracy of dual-source computed tomography in the diagnosis of coronary artery disease. Invest Radiol 2007;42:684-91.

54 Kaiser C, Bremerich J, Haller S, Brunner-La Rocca HP, Bongartz G, Pfisterer M, et al. Limited diagnostic yield of non-invasive coronary angiography by 16 -slice multi-detecto spiral computed tomography in routine patients referred for evaluation of coronary artery disease. Eur Heart J 2005;26:1987-92.

55 Kefer J, Coche E, Legros G, Pasquet A, Grandin C, Van Beers BE, et al. Head-to-head comparison of three-dimensional navigator-gated magnetic resonance imaging and 16 -slice computed tomography to detect coronary artery stenosis in patients. J Am Coll Cardiol 2005;46:92-100

56 Kolnes K, Velle OH, Hareide S, Hegbom K, Wiseth R. Multislice computed tomography coronary angiography at a local hospital: Pitfalls and potential. Acta Radiol 2006;47:680-6.

57 Laissy JP, Messika-Zeitoun D, Serfaty JM, Sebban V, Schouman-Claeys E, lung B, et al. Comprehensive evaluation of preoperative patients with aortic valve stenosis: usefulness of cardiac multidetector computed tomography. Heart 2007;93:1121-5.

58 Langer C, Peterschroder A, Franzke K, Esdorn H, Korperich H, Meyer H, et al. Noninvasive coronary angiography focusing on calcification: multislice computed tomography compared with magnetic resonance imaging. J Comput Assist Tomogr 2009;33(2):179-85.

59 Leber AW, Johnson T, Becker A, von Ziegler F, Tittus J, Nikolaou K, et al. Diagnostic accuracy of dual-source multi-slice CT-coronary angiography in patients with an intermediate pretest likelihood for coronary artery disease. Eur Heart J 2007;28:2354-60.

60 Leschka S, Alkadhi H, Plass A, Desbiolles L, Grunenfelder J, Marincek B, et al. Accuracy of MSCT coronary angiography with 64-slice technology: first experience. Eur Heart J 2005;26:1482-7.

61 Leschka S, Scheffel H, Desbiolles L, Plass A, Gaemperli O, Stolzmann P, et al. Combining dual-source computed tomography coronary angiography and calcium scoring: added value for the assessment of coronary artery disease. Heart 2008;94:1154-61.

62 Leschka S, Scheffel H, Husmann L, Gamperli O, Marincek B, Kaufmann PA, et al. Effect of decrease in heart rate variability on the diagnostic accuracy of 64-MDCT coronary angiography. AJR Am J Roentgenol 2008;190:1583-90.

63 Maintz D, Ozgun M, Hoffmeier A, Quante M, Fischbach R, Manning WJ, et al. Whole-heart coronary magnetic resonance angiography: value for the detection of coronary artery tenoses in comparison to multislice computed tomography angiography. Acta Radiol 2007:48:967-73

64 Manghat NE, Morgan-Hughes GJ, Shaw SR, Broadley AJ, Gogola L, Marshall AJ, et al. Multi-detector row CT coronary angiography in patients with cardiomyopathy-initial single-centre experience. Clin Radiol 2007;62:632-8.

65 Marano R, De Cobelli F, Floriani I, Becker C, Herzog C, Centonze M, et al. Italian multicenter, prospective study to evaluate the negative predictive value of 16 - and 64-slice MDCT imaging in patients scheduled for coronary angiography (NIMISCAD-Non Invasive Multicenter Italian Study for Coronary Artery Disease). Eur Radiol 2009;19:1114-23.

66 Martuscelli E, Romagnoli A, D'Eliseo A, Razzini C, Tomassini M, Sperandio M, et al. Accuracy of thin-slice computed tomography in the detection of coronary stenoses. Eur Heart J 2004;25:1043-8.

67 Maruyama T, Takada M, Hasuike T, Yoshikawa A, Namimatsu E, Yoshizumi T. Radiation Dose Reduction and Coronary Assessability of Prospective Electrocardiogram-Gated Computed Tomography Coronary Angiography. Comparison With Retrospective Electrocardiogram-Gated Helical Scan. J Am Coll Cardiol 2008;52:1450-5.

68 Meijboom WB, Meijs MF, Schuijf JD, Cramer MJ, Mollet NR, van Mieghem CA, et al. Diagnostic accuracy of 64-slice computed tomography coronary angiography: a prospective, multicenter, multivendor study. J Am Coll Cardiol 2008;52:2135-44.

69 Meijboom WB, Mollet NR, Van Mieghem CA, Kluin J, Weustink AC, Pugliese F, et al. Pre-operative computed tomography coronary angiography to detect significant coronary artery disease in patients referred for cardiac valve surgery. J Am Coll Cardiol 2006;48:1658-65

70 Meijboom WB, Mollet NR, Van Mieghem CA, Weustink AC, Pugliese F, van Pelt N, et al. 64-Slice CT coronary angiography in patients with non-ST elevation acute coronary syndrome. Heart 2007:93:1386-92.

71 Miller JM, Rochitte CE, Dewey M, Arbab-Zadeh A, Niinuma H, Gottlieb I, et al. Diagnostic performance of coronary angiography by 64-row CT. N Engl J Med 2008;359(22):2324-36.

72 Mir-Akbari H, Ripsweden J, Jensen J, Pichler P, Sylven C, Cederlund K, et al. Limitations of 64-detector-row computed tomography coronary angiography: calcium and motion but not short experience. Acta Radiol 2009;50:174-80.

73 Mollet NR, Cademartiri F, Krestin GP, McFadden EP, Arampatzis CA, Serruys PW, et al. Improved diagnostic accuracy with 16-row multi-slice computed tomography coronary angiography. J Am Coll Cardiol 2005;45:128-32.

74 Mollet NR, Cademartiri F, Nieman K, Saia F, Lemos PA, McFadden EP, et al. Multislice spiral computed tomography coronary angiography in patients with stable angina pectoris. J Am Coll Cardiol 2004;43:2265-70.

75 Mollet NR, Cademartiri F, van Mieghem CAG, Runza G, McFadden EP, Baks T, et al. High-resolution spiral computed tomography coronary angiography in patients referred for diagnostic conventional coronary angiography. Circulation 2005;112:2318-23.

76 Moon JY, Chung N, Choi BW, Choe KO, Seo HS, Ko YG, et al. The utility of multi-detector row spiral CT for detection of coronary artery stenoses. Yonsei Med J 2005;46:86-94.

77 Morgan-Hughes GJ, Roobottom CA, Owens PE, Marshall AJ. Highly accurate coronary angiography with submillimetre, 16 slice computed tomography. Heart 2005;91:308-13.

78 Nikolaou K, Knez A, Rist C, Wintersperger BJ, Leber A, Johnson T, et al. Accuracy of $64-M D C T$ in the diagnosis of ischemic heart disease. AJR Am J Roentgenol 2006;187:111-7.

79 Nikolaou K, Rist C, Wintersperger BJ, Jakobs TF, Van Gessel R, Kirchin MA, et al. Clinical value of MDCT in the diagnosis of coronary artery disease in patients with a low pretest likelihood of significant disease. AJR Am J Roentgenol 2006;186:1659-68.

80 Olivetti L, Mazza G, Volpi D, Costa F, Ferrari O, Pirelli S. Multislice CT in emergency room management of patients with chest pain and medium-low probability of acute coronary syndrome. Radiol Med (Torino) 2006;111:1054-63.

81 Oncel D, Oncel G, Tastan A. Effectiveness of dual-source CT coronary angiography for the evaluation of coronary artery disease in patients with atrial fibrillation: initial experience. Radiology 2007;245:703-11

82 Oncel D, Oncel G, Tastan A, Tamci B. Detection of significant coronary artery stenosis with 64-section MDCT angiography. Eur J Radiol 2007;62:394-405.

83 Pontone G, Andreini D, Ballerini G, Nobili E, Pepi M. Diagnostic work-up of unselected patients with suspected coronary artery disease: complementary role of multidetector computed tomography, symptoms and electrocardiogram stress test. Coron Artery Dis 2007;18:265-74.

84 Pontone G, Andreini D, Quaglia C, Ballerini G, Nobili E, Pepi M. Accuracy of multidetector spiral computed tomography in detecting significant coronary stenosis in patient populations with differing pre-test probabilities of disease. Clin Radiol 2007;62:978-85.

85 Postel T, Frick M, Feuchtner G, Alber H, Zwick R, Suessenbacher A, et al. Role of 16-multidetector computed tomography in the assessment of coronary artery stenoses: A prospective study of consecutive patients. Exp Clin Cardiol 2007;12:149-52.

86 Pouleur AC, de Waroux JBL, Kefer J, Pasquet A, Vanoverschelde JL, Gerber BL. Direc comparison of whole-heart navigator-gated magnetic resonance coronary angiography and 40-and 64-slice multidetector row computed tomography to detect the coronary artery stenosis in patients scheduled for conventional coronary angiography. Circ Cardiovasc Imaging 2008;1:114-21.

87 Pugliese F, Mollet NR, Runza G, van Mieghem C, Meijboom WB, Malagutti P, et al. Diagnostic accuracy of non-invasive 64-slice CT coronary angiography in patients with stable angina pectoris. Eur Radiol 2006;16:575-82.

88 Pundziute G, Schuijf JD, Jukema JW, van Werkhoven JM, Boersma E, de Roos A, et al. Gender influence on the diagnostic accuracy of 64-slice multislice computed tomography coronary angiography for detection of obstructive coronary artery disease. Heart 2008;94:48-52.

89 Raff GL, Gallagher MJ, O'Neill WW, Goldstein JA. Diagnostic accuracy of noninvasive coronary angiography using 64-slice spiral computed tomography. J Am Coll Cardiol 2005:46:552-7.

90 Reant P, Brunot S, Lafitte S, Serri K, Leroux L, Corneloup O, et al. Predictive value of noninvasive coronary angiography with multidetector computed tomography to detect significant coronary stenosis before valve surgery. Am J Cardiol 2006;97:1506-10.

91 Rixe J, Rolf A, Conradi G, Moellmann H, Nef H, Neumann T, et al. Detection of relevan coronary artery disease using dual-source computed tomography in a high probability patient series: -comparison with invasive angiography. Circ J 2009;73:316-22.

92 Rodevand O, Hogalmen G, Gudim LP, Indrebo T, Molstad P, Vandvik PO. Limited usefulness of non-invasive coronary angiography with 16-detector multislice computer tomography at a community hospital. Scand Cardiovasc J 2006;40(2):76-82.

93 Romeo F, Leo R, Clementi F, Razzini C, Borzi M, Martuscelli E, et al. Multislice computed tomography in an asymptomatic high-risk population. Am J Cardiol 2007;99:325-8. 
94 Ropers D, Baum U, Pohle K, Anders K, Ulzheimer S, Ohnesorge B, et al. Detection of coronary artery stenoses with thin-slice multi-detector row spiral computed tomography and multiplanar reconstruction. Circulation 2003;107:664-6.

95 Ropers D, Rixe J, Anders K, Kuttner A, Baum U, Bautz W, et al. Usefulness of multidetector row spiral computed tomography with $64-\times 0.6-\mathrm{mm}$ collimation and 330 -ms rotation for the noninvasive detection of significant coronary artery stenoses. Am J Cardiol 2006:97:343-8.

96 Ropers U, Ropers D, Pflederer T, Anders K, Kuettner A, Stilianakis NI, et al. Influence of heart rate on the diagnostic accuracy of dual-source computed tomography coronary angiography. J Am Coll Cardiol 2007;50:2393-8.

97 Scheffel H, Alkadhi H, Leschka S, Plass A, Desbiolles L, Guber I, et al. Low-dose CT coronary angiography in the step-and-shoot mode: Diagnostic performance. Heart 2008;94:1132-7.

98 Scheffel H, Alkadhi H, Plass A, Vachenauer R, Desbiolles L, Gaemperli O, et al. Accuracy of dual-source $\mathrm{CT}$ coronary angiography: First experience in a high pre-test probability population without heart rate control. Eur Radiol 2006;16:2739-47.

99 Scheffel H, Leschka S, Plass A, Vachenauer R, Gaemperli O, Garzoli E, et al. Accuracy of 64-slice computed tomography for the preoperative detection of coronary artery disease in patients with chronic aortic regurgitation. Am J Cardiol 2007;100:701-6.

100 Schuijf JD, Pundziute G, Jukema JW, Lamb HJ, van der Hoeven BL, de Roos A, et al. Diagnostic accuracy of 64 -slice multislice computed tomography in the noninvasive evaluation of significant coronary artery disease. Am J Cardiol 2006;98:145-8.

101 Shabestari AA, Abdi S, Akhlaghpoor S, Azadi M, Baharjoo H, Pajouh MD, et al. Diagnostic performance of 64-channel multislice computed tomography in assessment of significan coronary artery disease in symptomatic subjects. Am J Cardiol 2007;99:1656-61.

102 Stolzmann P, Scheffel H, Leschka S, Plass A, Baumuller S, Marincek B, et al. Influence of calcifications on diagnostic accuracy of coronary $\mathrm{CT}$ angiography using prospective ECG triggering. AJR Am J Roentgenol 2008;191:1684-9.

103 Tsai IC, Lee T, Lee WL, Tsao CR, Tsai WL, Chen MC, et al. Use of 40-detector row computed tomography before catheter coronary angiography to select early conservative versus early invasive treatment for patients with low-risk acute coronary syndrome. $J$ Comput Assist Tomogr 2007;31:258-64.

104 Turkvatan A, Biyikoglu SF, Buyukbayraktar F, Olcer T, Cumhur T, Duru E. Clinical value of 16 -slice multidetector computed tomography in symptomatic patients with suspected coronary artery disease. Acta Radiol 2008;49:400-8.

105 Ulimoen GR, Gjonnaess E, Atar D, Dahl T, Stranden E, Sandbaek G. Noninvasive coronary angiography with 64-channel multidetector computed tomography in patients with acute coronary syndrome. Acta Radiol 2008:49:1140-4

106 Watkins MW, Hesse B, Green CE, Greenberg NL, Manning M, Chaudhry E, et al. Detection of coronary artery stenosis using 40-channel computed tomography with multi-segment reconstruction. Am J Cardiol 2007;99:175-81.

107 Weustink AC, Meijboom WB, Mollet NR, Otsuka M, Pugliese F, van Mieghem C, et al. Reliable high-speed coronary computed tomography in symptomatic patients. J Am Coll Cardiol 2007;50:786-94.

108 Alkadhi H, Stolzmann P, Desbiolles L, Baumueller S, Goetti R, Plass A, et al. Low-dose, 128-slice, dual-source CT coronary angiography: Accuracy and radiation dose of the high-pitch and the step-and-shoot mode. Heart 2010;96:933-8.

109 Andreini D, Pontone G, Bartorelli AL, Agostoni P, Mushtaq S, Bertella E, et al. Sixty-four-slice multidetector computed tomography: an accurate imaging modality for the evaluation of coronary arteries in dilated cardiomyopathy of unknown etiology. Circ Cardiovasc Imaging 2009;2:199-205.

110 Bettencourt N, Rocha J, Carvalho M, Leite D, Toschke AM, Melica B, et al. Multislice computed tomography in the exclusion of coronary artery disease in patients with presurgical valve disease. Circ Cardiovasc Imaging 2009;2:306-13

111 Boulmier D, Audinet C, Heautot JF, Larralde A, Veillard D, Hamonic S, et al. Clinical contributions of 64-slice computed tomography in the evaluation of cardiomyopathy of unknown origin. Arch Cardiovasc Dis 2009;102:685-96.

112 Cademartiri F, La Grutta L, Palumbo A, Maffei E, Martini C, Seitun S, et al. Computed tomography coronary angiography vs. stress ECG in patients with stable angina. [Italian, English]. Radiologia Medica 2009;114:513-23.

113 Cademartiri F, Maffei E, Palumbo A, Martini C, Seitun S, Tedeschi C, et al. Diagnostic accuracy of computed tomography coronary angiography in patients with a zero calcium score. Eur Radiol 2010;20:81-7.

114 Carrascosa P, Capunay C, Deviggiano A, Bettinotti M, Goldsmit A, Tajer C, et al. Feasibility of 64-slice gadolinium-enhanced cardiac CT for the evaluation of obstructive coronary artery disease. Heart 2010;96:1543-9

115 Carrascosa P, Capunay C, Deviggiano A, Goldsmit A, Tajer C, Bettinotti M, et al. Accuracy of low-dose prospectively gated axial coronary $\mathrm{CT}$ angiography for the assessment of coronary artery stenosis in patients with stable heart rate. J Cardiovasc Comput Tomogr 2010;4:197-205

116 De Graaf FR, Schuijf JD, Van Velzen JE, Kroft LJ, De Roos A, Reiber JHC, et al. Diagnostic accuracy of 320-row multidetector computed tomography coronary angiography in the non-invasive evaluation of significant coronary artery disease. Eur Heart $J$ 2010;31:1908-15.

117 Diederichsen AC, Petersen H, Jensen LO, Thayssen P, Gerke O, Sandgaard NC, et al. Diagnostic value of cardiac 64 -slice computed tomography: importance of coronary calcium. Scand Cardiovasc J 2009:43:337-44

118 Donati OF, Scheffel H, Stolzmann P, Baumuller S, Plass A, Leschka S, et al. Combined cardiac $\mathrm{CT}$ and $\mathrm{MRI}$ for the comprehensive workup of hemodynamically relevant coronary stenoses. AJR Am J Roentgenol 2010;194:920-6.

119 Hamdan A, Asbach P, Wellnhofer E, Klein C, Gebker R, Kelle S, et al. A prospective study for comparison of MR and $\mathrm{CT}$ imaging for detection of coronary artery stenosis. JACC Cardiovasc Imaging 2011;4:50-61.

120 Husmann L, Herzog BA, Burger IA, Buechel RR, Pazhenkottil AP, von Schulthess P, et al. Usefulness of additional coronary calcium scoring in low-dose CT coronary angiography with prospective ECG-triggering. Impact on total effective radiation dose and diagnostic accuracy. Acad Radiol 2010;17(2):201-06.

121 Jenkins SMM, Johnston N, Hawkins NM, Messow CM, Shand J, Hogg KJ, et al. Limited clinical utility of CT coronary angiography in a district hospital setting. QJM2011;104:49-57.

122 LaBounty TM, Leipsic J, Mancini GB, Heilbron B, Patel S, Kazerooni EA, et al. Effect of a standardized radiation dose reduction protocol on diagnostic accuracy of coronary computed tomographic angiography. Am J Cardiol 2010;106:287-92.

123 Meng L, Cui L, Cheng Y, Wu X, Tang Y, Wang Y, et al. Effect of heart rate and coronary calcification on the diagnostic accuracy of the dual-source CT coronary angiography in patients with suspected coronary artery disease. Korean J Radiol 2009;10:347-54.

124 Nazeri I, Shahabi P, Tehrai M, Sharif-Kashani B, Nazeri A. Impact of calcification on diagnostic accuracy of 64-slice spiral computed tomography for detecting coronary artery disease: a single center experience. Arch Iran Med 2010;13:373-83.

125 Ovrehus KA, Jensen JK, Mickley HF, Munkholm H, Bottcher M, Botker HE, et al. Comparison of usefulness of exercise testing versus coronary computed tomographic angiography for evaluation of patients suspected of having coronary artery disease. Am J Cardiol 2010;105:773-9.

126 Pontone G, Andreini D, Bartorelli AL, Cortinovis S, Mushtaq S, Bertella E, et al. Diagnostic accuracy of coronary computed tomography angiography: a comparison between prospective and retrospective electrocardiogram triggering. J Am Coll Cardiol 2009;54:346-55.

127 Rocha-Filho JA, Blankstein R, Shturman LD, Bezerra HG, Okada DR, Rogers IS, et al. Incremental value of adenosine-induced stress myocardial perfusion imaging with dual-source CT at cardiac CT angiography. Radiology 2010;254:410-9.

128 Romagnoli A, Martuscelli E, Sperandio M, Arganini C, De Angelis B, Acampora V, et al. Role of 64-slice cardiac computed tomography in the evaluation of patients with non-ST-elevation acute coronary syndrome. Radiologia Medica 2010;115:341-53.

129 Sato A, Nozato T, Hikita H, Miyazaki S, Takahashi Y, Kuwahara T, et al. Incremental value of combining 64-slice computed tomography angiography with stress nuclear myocardial perfusion imaging to improve noninvasive detection of coronary artery disease. J Nucl Cardiol 2010;17:19-26.

130 Sheikh M, Ben-Nakhi A, Shukkur AM, Sinan T, Al-Rashdan I. Accuracy of 64-multidetector-row computed tomography in the diagnosis of coronary artery disease. Med Princ Pract 2009;18:323-8.

131 Stagnaro N, Della Latta D, Chiappino D. Diagnostic accuracy of MDCT coronary angiography in patients referred for heart valve surgery. [Italian, English]. Radiologia Medica 2009;114:728-42.

132 Thomas C, Brodoefel H, Tsiflikas I, Bruckner F, Reimann A, Ketelsen D, et al. Does clinical pretest probability influence image quality and diagnostic accuracy in dual-source coronary CT angiography? Acad Radiol 2010;17:212-8.

133 Ugolini P, Pressacco J, Lesperance J, Berry C, L'Allier PL, Ibrahim R, et al. Evaluation of coronary atheroma by 64 -slice multidetector computed tomography: comparison with intravascular ultrasound and angiography. Can J Cardiol 2009;25:641-7.

134 van Werkhoven JM, Heijenbrok MW, Schuijf JD, Jukema JW, Boogers MM, van der Wall $\mathrm{EE}$, et al. Diagnostic accuracy of 64 -slice multislice computed tomographic coronary angiography in patients with an intermediate pretest likelihood for coronary artery disease. Am J Cardiol 2010;105:302-5.

135 Xu L, Yang L, Fan Z, Yu W, Lv B, Zhang Z. Diagnostic performance of 320-detector CT coronary angiography in patients with atrial fibrillation: preliminary results. Eur Radiol 2011;21:936-43

136 Yang L, Zhang Z, Fan Z, Xu C, Zhao L, Yu W, et al. 64-MDCT coronary angiography of patients with atrial fibrillation: Influence of heart rate on image quality and efficacy in evaluation of coronary artery disease. AJR Am J Roentgenol 2009;193:795-801.

137 Zhang LJ, Wu SY, Wang J, Lu Y, Zhang ZL, Jiang SS, et al. Diagnostic accuracy of dual-source CT coronary angiography: The effect of average heart rate, heart rate variability, and calcium score in a clinical perspective. Acta Radiol 2010;51:727-40.

138 Simel DL, Feussner JR, DeLong ER, Matchar DB. Intermediate, indeterminate, and uninterpretable diagnostic test results. Med Decis Making 1987;7:107-14.

139 Deeks JJ, Altman DG. Diagnostic tests 4: likelihood ratios. BMJ 2004;329:168-9.

140 Bossuyt PM, Reitsma JB, Bruns DE, Gatsonis CA, Glasziou PP, Irwig LM, et al. Towards complete and accurate reporting of studies of diagnostic accuracy: the STARD initiative. BMJ 2003;326:41-4

141 Whiting P, Rutjes AW, Reitsma JB, Bossuyt PM, Kleijnen J. The development of QUADAS: a tool for the quality assessment of studies of diagnostic accuracy included in systematic reviews. BMC Med Res Methodol 2003;3:25.

142 Whiting PF, Rutjes AW, Westwood ME, Mallett S, Deeks JJ, Reitsma JB, et al. QUADAS-2: a revised tool for the quality assessment of diagnostic accuracy studies. Ann Intern Med 2011;155:529-36.

143 Altman DG, Simera I. Responsible reporting of health research studies: transparent, complete, accurate and timely. J Antimicrob Chemother 2010;65:1-3.

144 Altman DG, Simera I, Hoey J, Moher D, Schulz K. EQUATOR: reporting guidelines for health research. Lancet 2008;371:1149-50.

\section{Accepted: 24 September 2012}

\section{Cite this as: BMJ 2012:345:e6717}

This is an open-access article distributed under the terms of the Creative Commons Attribution Non-commercial License, which permits use, distribution, and reproduction in any medium, provided the original work is properly cited, the use is non commercial and is otherwise in compliance with the license. See: http://creativecommons.org/licenses/bync/2.0/ and http://creativecommons.org/licenses/by-nc/2.0/legalcode. 


\section{Tables}

Table 1| Analysed studies with recalculated $3 \times 2$ tables including non-evaluable results

\begin{tabular}{|c|c|c|c|c|c|c|c|c|c|}
\hline \multirow[b]{3}{*}{ First author } & \multirow[b]{3}{*}{ Journal } & \multirow[b]{3}{*}{ Year } & \multirow[b]{3}{*}{$\begin{array}{l}\text { Handling of non-evaluable } \\
\text { segments at patient level }\end{array}$} & \multicolumn{6}{|c|}{$3 \times 2$ table } \\
\hline & & & & \multicolumn{4}{|c|}{$2 \times 2$ table } & \multicolumn{2}{|c|}{$\begin{array}{c}\text { Non-evaluable results }(\mathrm{CT}) \text { at } \\
\text { patient level }\end{array}$} \\
\hline & & & & $\begin{array}{l}\text { True } \\
\text { positive }\end{array}$ & $\begin{array}{c}\text { False } \\
\text { positive }\end{array}$ & $\begin{array}{c}\text { False } \\
\text { negative }\end{array}$ & $\begin{array}{c}\text { True } \\
\text { negative }\end{array}$ & $\begin{array}{l}\text { Non-evaluable } \\
\text { (positive) }\end{array}$ & $\begin{array}{c}\text { Non-evaluable } \\
\text { (negative) }\end{array}$ \\
\hline Achenbach S & Eur Heart J & 2005 & $\begin{array}{l}\text { Patients considered to be } \\
\text { negative }\end{array}$ & 25 & 4 & 0 & 19 & 2 & 0 \\
\hline Alkadhi $\mathrm{H}$ & Eur Heart J & 2008 & $\begin{array}{l}\text { Patients considered to be } \\
\text { positive }\end{array}$ & 57 & 3 & 2 & 79 & 0 & 9 \\
\hline Bonmassari R & $J$ Cardiovasc Med & 2006 & Patients excluded & 12 & 2 & 0 & 8 & 2 & 9 \\
\hline Boulmier D & $\begin{array}{l}\text { Arch Cardiovasc } \\
\text { Dis }\end{array}$ & 2009 & $\begin{array}{l}\text { Patients considered to be } \\
\text { positive }\end{array}$ & 12 & 4 & 0 & 37 & 0 & 6 \\
\hline Cademartiri F & Radiol Med & 2009 & Patients excluded & 31 & 1 & 0 & 9 & 0 & 1 \\
\hline Carrascosa P & $\begin{array}{l}\text { J Cardiovasc } \\
\text { Comput Tomogr }\end{array}$ & 2010 & $\begin{array}{l}\text { Patients considered to be } \\
\text { positive }\end{array}$ & 26 & 3 & 0 & 18 & 0 & 3 \\
\hline Cornily JC & Eur J Radiol & 2007 & Patients excluded & 9 & 1 & 0 & 23 & 1 & 2 \\
\hline de Graaf FR & Eur Heart J & 2010 & $\begin{array}{l}\text { Patients considered to be } \\
\text { positive }\end{array}$ & 35 & 3 & 0 & 22 & 2 & 2 \\
\hline Dewey M & Ann Intern Med & 2006 & $\begin{array}{l}\text { Intention to diagnose }(3 \times 2 \\
\text { table })\end{array}$ & 62 & 5 & 4 & 46 & 1 & 11 \\
\hline Dewey M & Circulation & 2009 & $\begin{array}{l}\text { Intention to diagnose }(3 \times 2 \\
\text { table })\end{array}$ & 11 & 1 & 0 & 17 & 0 & 0 \\
\hline Garcia MJ & $J A M A$ & 2006 & $\begin{array}{l}\text { Patients considered to be } \\
\text { positive }\end{array}$ & 44 & 29 & 1 & 70 & 14 & 29 \\
\hline Gilard M & J Am Coll Cardiol & 2006 & $\begin{array}{l}\text { Patients considered to be } \\
\text { positive }\end{array}$ & 6 & 0 & 0 & 35 & 5 & 9 \\
\hline Hausleiter J & Eur Heart J & 2007 & $\begin{array}{l}\text { Patients considered to be } \\
\text { positive }\end{array}$ & 91 & 19 & 1 & 106 & 10 & 16 \\
\hline Herzog BA & Eur Heart J & 2008 & $\begin{array}{l}\text { Patients considered to be } \\
\text { positive }\end{array}$ & 16 & 0 & 0 & 10 & 2 & 2 \\
\hline Jenkins SMM & QJ Med & 2011 & $\begin{array}{l}\text { Patients considered to be } \\
\text { positive, } 3 \times 2 \text { table given }\end{array}$ & 27 & 8 & 3 & 29 & 8 & 24 \\
\hline Leschka S & $\begin{array}{l}\text { AJR Am J } \\
\text { Roentgenol }\end{array}$ & 2008 & $\begin{array}{l}\text { Patients considered to be } \\
\text { positive }\end{array}$ & 69 & 6 & 2 & 35 & 0 & 2 \\
\hline Leschka S & Heart & 2008 & $\begin{array}{l}\text { Patients considered to be } \\
\text { positive }\end{array}$ & 35 & 1 & 1 & 33 & 0 & 4 \\
\hline Leschka S & Eur Radiol & 2009 & $\begin{array}{l}\text { Patients considered to be } \\
\text { positive }\end{array}$ & 14 & 1 & 0 & 19 & 0 & 1 \\
\hline Mir-Akbari H & Acta Radiol & 2009 & $\begin{array}{l}\text { Patients considered to be } \\
\text { positive }\end{array}$ & 41 & 11 & 0 & 20 & 10 & 19 \\
\hline Ovrehus KA & Am J Cardiol & 2010 & $\begin{array}{l}\text { Patients considered to be } \\
\text { positive }\end{array}$ & 26 & 11 & 1 & 57 & 2 & 3 \\
\hline Pontone $\mathrm{G}$ & J Am Coll Cardiol & 2009 & $\begin{array}{l}\text { Patients considered to be } \\
\text { positive }\end{array}$ & 142 & 2 & 2 & 14 & 0 & 0 \\
\hline Ropers U & J Am Coll Cardiol & 2007 & $\begin{array}{l}\text { Patients considered to be } \\
\text { positive }\end{array}$ & 39 & 10 & 1 & 47 & 2 & 1 \\
\hline Sato $A$ & J Nucl Cardiol & 2010 & Patients excluded & 61 & 8 & 1 & 37 & 15 & 8 \\
\hline Scheffel $\mathrm{H}$ & Am J Cardiol & 2007 & $\begin{array}{l}\text { Patients considered to be } \\
\text { positive }\end{array}$ & 12 & 0 & 0 & 35 & 1 & 2 \\
\hline Scheffel H & Heart & 2008 & $\begin{array}{l}\text { Patients considered to be } \\
\text { positive }\end{array}$ & 64 & 2 & 0 & 50 & 2 & 2 \\
\hline Ulimoen GR & Acta Radiol & 2008 & $\begin{array}{l}\text { Non-evaluable segments } \\
\text { excluded }\end{array}$ & 32 & 6 & 4 & 6 & 10 & 0 \\
\hline Naive s & nmary $3 \times 2$ table valu & that do $\mathrm{n}$ & $t$ represent the statistical model & 999 & 141 & 23 & 881 & 89 & 165 \\
\hline
\end{tabular}


Table 2| Effects of different ways of handling non-evaluable results on pooled diagnostic accuracy values

\begin{tabular}{|c|c|c|c|c|c|}
\hline Basis for calculation & $\begin{array}{l}\text { Mean sensitivity }(95 \% \\
\mathrm{Cl})\end{array}$ & $\begin{array}{l}\text { Mean specificity }(95 \% \\
\mathrm{Cl})\end{array}$ & $\begin{array}{l}\text { Area under the curve } \\
\qquad(95 \% \mathrm{Cl})\end{array}$ & $\begin{array}{l}\text { Positive likelihood } \\
\text { ratio }(95 \% \mathrm{Cl})\end{array}$ & $\begin{array}{l}\text { Negative likelihood ratio } \\
\qquad(95 \% \mathrm{Cl})\end{array}$ \\
\hline $\begin{array}{l}2 \times 2 \text { table (non-evaluable results } \\
\text { excluded) }\end{array}$ & $98.2(96.7 \text { to } 99.1)^{*}$ & 89.2 (84.2 to 92.8$)$ & $0.99(0.98 \text { to } 1.00)^{*}$ & $9.1(6.2 \text { to } 13.3)^{\star}$ & $0.02(0.01 \text { to } 0.04)^{*}$ \\
\hline $\begin{array}{l}\text { Non-evaluable patients } \\
\text { considered as positive }\end{array}$ & $98.3(96.9 \text { to } 99.0)^{*}$ & 78.4 (71.6 to 84.0$)$ & $0.98(0.97 \text { to } 0.99)^{*}$ & 4.5 (3.5 to 6.0$)$ & $0.02(0.01 \text { to } 0.04)^{*}$ \\
\hline $\begin{array}{l}\text { Non-evaluable patients } \\
\text { considered as negative }\end{array}$ & 92.9 (88.8 to 95.5$)$ & $90.5(86.8 \text { to } 93.2)^{*}$ & 0.96 (0.94 to 0.98$)$ & $9.8(7.0 \text { to } 13.7)^{*}$ & $0.08(0.05$ to 0.13$)$ \\
\hline $\begin{array}{l}3 \times 2 \text { table (intention to diagnose } \\
\text { approach) }\end{array}$ & 92.7 (88.5 to 95.3$)$ & 79.0 (72.3 to 84.4$)$ & 0.93 (0.91 to 0.95$)$ & 4.4 (3.3 to 6.0$)$ & 0.09 (0.06 to 0.15$)$ \\
\hline
\end{tabular}

*Significantly different $(\mathrm{P}<0.05)$ from data obtained by use of $3 \times 2$ table. 


\section{Figures}

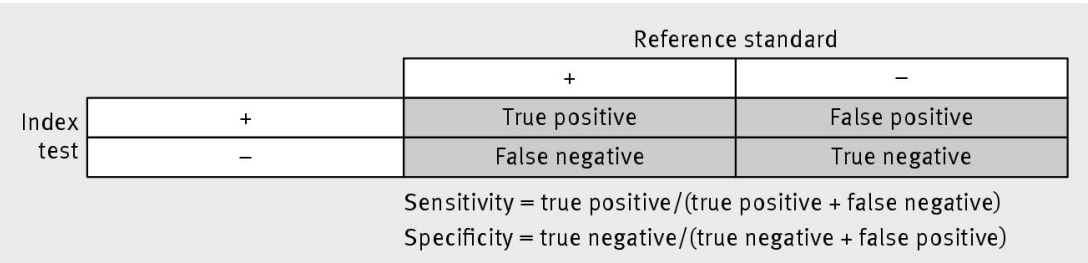

Fig 1 The "classic" $2 \times 2$ table, calculation of sensitivity and specificity

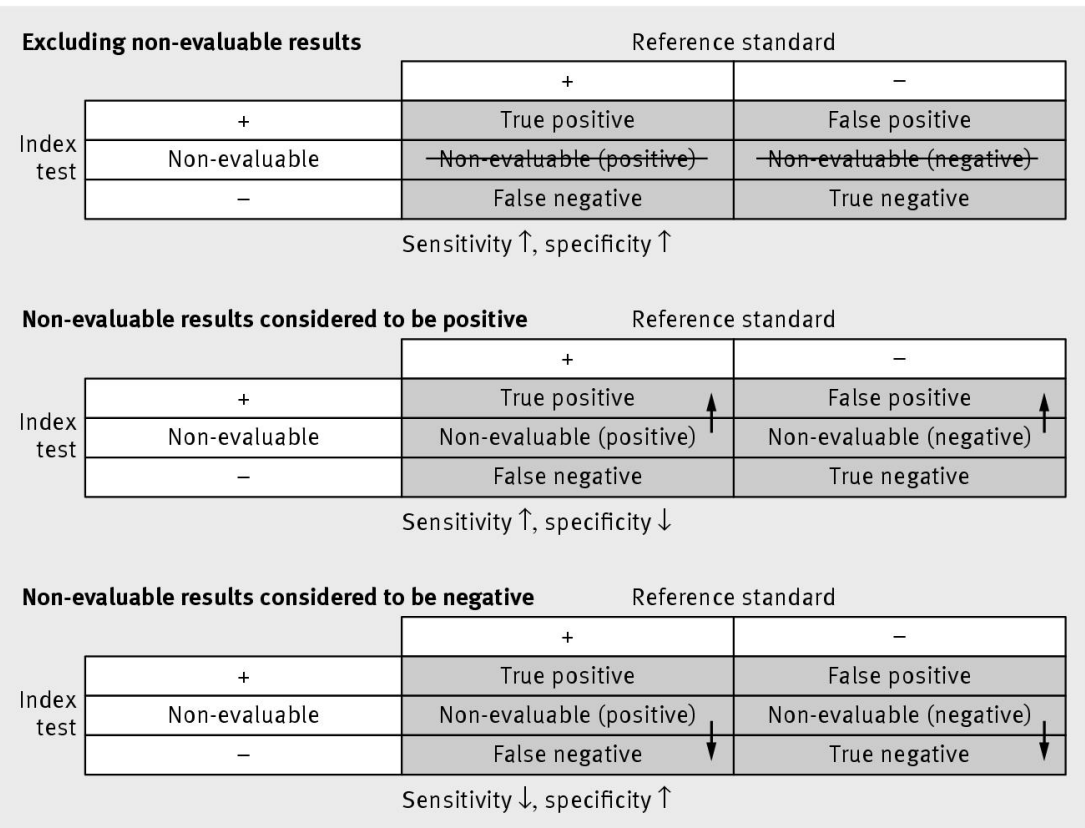

Fig 2 Different methods of handling non-evaluable results

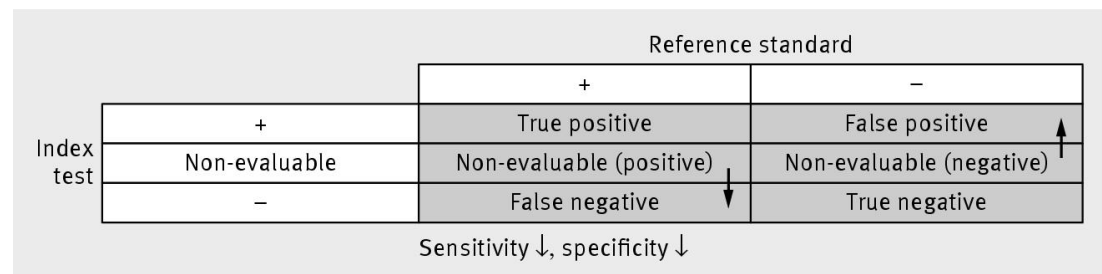

Fig $33 \times 2$ table and intention to diagnose principle 


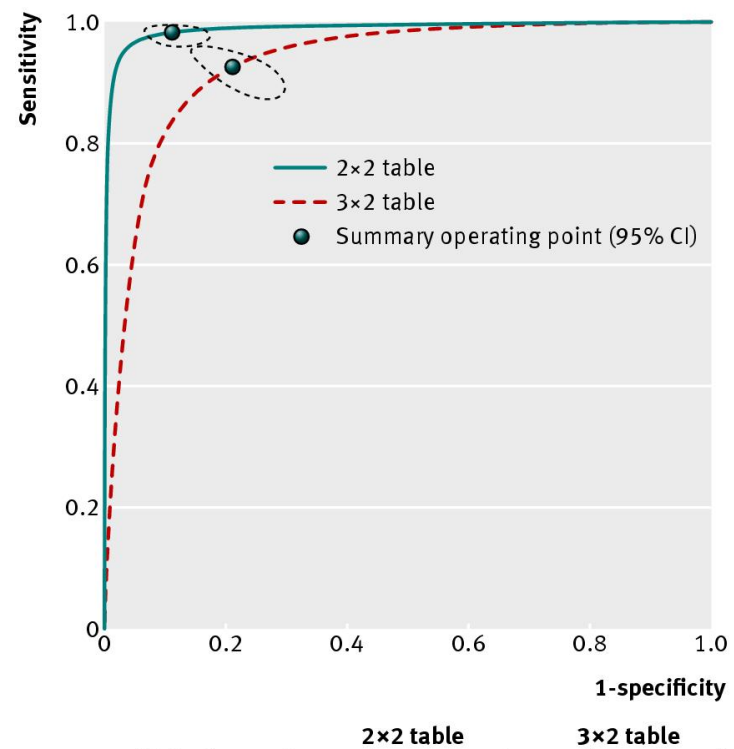

Sensitivity $(95 \% \mathrm{Cl}) \quad 0.98(0.97$ to 0.99$) \quad 0.93(0.89$ to 0.95$)$ Specificity $(95 \% \mathrm{CI}) \quad 0.89(0.84$ to 0.93$) 0.79(0.73$ to 0.84$)$ AUC ( $95 \% \mathrm{Cl}) \quad 0.99(0.98$ to 1.00$) \quad 0.93(0.91$ to 0.95$)$

Fig 4 Summary receiver operating characteristics curves for $2 \times 2$ and $3 \times 2$ tables. The graph shows summary receiver operating characteristics curves using pairs of sensitivity and specificity of the 26 studies that provided enough background information to construct $3 \times 2$ tables. The upper left curve is based on the results of the studies when excluding non-evaluable results $(2 \times 2$ table), the lower right curve when including them as either false positives or false negatives according to the results of the reference standard ( $3 \times 2$ table with an intention to diagnose approach). Curves include a summary operating point for sensitivity and specificity on the curve and a $95 \%$ confidence contour ellipsoid 